\title{
Muslim Areas at Municipal Cemeteries in Germany and Austria ${ }^{1}$
}

\author{
Martin Klapetek \\ Department of Philosophy and Study of Religions \\ University of South Bohemia in České Budějovice \\ klapetek.martin@gmail.com
}

\begin{abstract}
The paper is devoted to funeral culture and its connection to the acculturation of Muslims in German and Austrian society. The vast majority of the deceased are still transported back to their country of origin, which hampers the successful integration of their families. With regard to the establishment of specialised areas within municipal cemeteries, the significance of the process of institutionalisation of Muslim organisations has become clear, as has the emphasis on experts. An increase in the number of Muslim burials in Western Europe is expected in future. Importance is also attached to the funerals of new-borns, but the long-term integration effect of such funerals on the whole family is still debatable. Problems with operation of Islamic cemeteries in Germany are influenced by conferring public rights on Muslim organisations. However, some examples of successful operation of Islamic cemeteries can already be found in Austria. The current situation is influenced by the need to respond to an ever-increasing number of seniors from the first generation of Muslim migrants and asylum seekers from the second half of the last century. The creation of special areas at municipal cemeteries may not actually constitute an expression of separation. It rather corresponds to the process of integration within a stratified society. The forms of Islamic funerals will change as they adapt to the new environment. The cultural interpretations of Islam not only confront each other but also respond to the funeral customs of the surrounding non-Muslim society.
\end{abstract}

Keywords: Islam, funeral, cemetery, areas in cemeteries, Germany, Austria Słowa kluczowe: islam, pogrzeb, cmentarz, kwatery grzebalne, Niemcy, Austria

${ }^{1}$ This article was prepared within the framework of grant project No. 14-16520S ("Death, Graves, and the Hereafter in Islam: Muslim Perceptions of the Last Things in the Middle Ages and Today"), funded by the Czech Science Foundation (GAČR). 


\section{Introduction}

The key focus of this text is the process of acculturation that has taken place among the Muslim populations in German and Austrian society in relation to issues associated with funeral culture. By studying individual solutions devised to address problems associated with building special areas at municipal cemeteries, a number of themes will be identified which can be interpreted as supporting assimilation, integration, or separation. Therefore the main research question is whether the request to establish such areas expresses separation. Consequently, the aim of the study is not simply to describe dying, death and eschatology in general terms and from the viewpoint of normative Islam, since there already exists a wealth of German academic literature on this topic. ${ }^{2}$ Likewise, it is now possible to access publications tracing the history of Muslim funeral culture in Germany over the past six centuries. ${ }^{3}$

The study is a result of research during which the following methods were used: critical analysis of academic literature, non-participant observation, analysis of selfpresentation, photo documentation and description of locations. With regard to the methodological approach, the more generally framed text is based on an analysis and comparison of examples from German and Austrian sites visited during research visits conducted between 2011 and 2015. ${ }^{4}$

\section{Background and context}

In the broader historical context, Germany and Austria can boast a rich experience in relation to traditionally Muslim countries and presence of Islam in Europe. These are important variables that continue to influence their general view of this religious system and its believers. As a result of the flow of economic migrants during the second half of the twentieth century, the foundations of Muslim institutions in Germany and Austria were gradually laid, and this certainly had a significant influence on the current form of Islam in the countries concerned. ${ }^{5}$ In addition to

${ }^{2}$ R. Sörries, Von Mekka bis Berlin. Archäologie und Kulturgeschichte des islamisches Friedhofs, Wiesbaden 2015; A. Eisingerich, Tod als Rückkehr zur Gott, der Quelle allen Lebens - Sterben, Tod und Trauer im Islam [in:] Aller Einkehr ist der Tod. Interreligiöse Zugänge zu Sterben, Tod und Trauer, B. Heller (ed.), Freiburg im Breisgau 2003, pp. 118-143.

${ }^{3}$ H. Heller, Muslime in deutscher Erde: Frühe Grabstätten des 14. bis 18. Jahrhunderts [in:] In fremder Erde. Zur Geschichte und Gegenwart der islamischen Bestattung in Deutschland, G. Höpp, J. Gerdien (eds.), Berlin 1996, pp. 45-62; G. Höpp, Tod und Geschichte oder Wie in Berlin prominente Muslime bestattet wurden [in:] In fremder Erde..., op.cit., pp. 19-44.

${ }^{4}$ The data was collected during a month-long research stay in Berlin supported by the Czech Ministry of Education, Youth and Sports. I analysed and compared this data with that obtained during stays in North Rhine-Westphalia, Hesse, Berlin and Vienna, supported by grant projects of the Czech Science Foundation. I offer my thanks for this support. I also thank the anonymous reviewers for their careful reading of my manuscript and their many insightful comments and suggestions, as well as Karel Pazourek, $\mathrm{PhD}$, for helping with the final version of the text.

${ }^{5}$ For the institutionalisation of Islam in Germany and Austria see M. Klapetek, Muslimské organizace v Německu, Rakousku a Švýcarsku, Brno 2011. 
the organisations operating at a nationwide level or within a specific federal state, independent mosque associations were established, their diverse activities aimed at the residents of specific towns and villages. However, this is only one aspect of the complex form of Islam established in these European countries, as it can be observed that the powerful influence of these organisations has had a long-term impact only on certain sections of the local Muslim population. ${ }^{6}$ Most of them, for various reasons, maintain a discrete distance from this institutional form of Islam, and their identity is defined to a much greater extent by cultural elements, which are mainly experienced individually or, at most, within the wider family circle. If we follow this issue over the long term and from the position of religious studies and other related disciplines, we discover, among other things, an interesting topic which, because of its specific nature, includes the aforementioned elements associated with the Muslim population. This topic relates to the current practice of Islamic funeral culture in Germany and Austria.

The so-called refugee crisis and its medium-term consequences mean that we now find ourselves in a somewhat turbulent period of history, which, in the author's opinion, provides us with an ideal opportunity to assess the broader implications of the current institutionalisation of Islam in these countries and to identify possible future trends. The significant demographic changes that are taking place will have an impact not only on all aspects of German and Austrian society, but also on local Muslim communities, which are subject to a far more pronounced Turkish cultural background in comparison to Islamic universalism. ${ }^{7}$ To a large extent, it can be stated that, as was the case with economic migration in the 1970s and 1980s, there is an expectation that the current high numbers of mostly Arab immigrants will be integrated within Western European societies. In the future, it may become apparent which of the institutions established in the past few decades actually lead to more successful integration of both the succeeding generations of local Muslims and also the new arrivals. There are two topics that focus on future development of Islam communities in Western Europe. One of them discusses the identity of thirdgeneration Muslims living in Europe, for example in connection with the threat posed by the influence of Salafi groups. Another topic is dealing with the retirement age of first-generation Muslims. ${ }^{8}$ This is, therefore, an appropriate time to conduct an evaluation of the period before the changes associated with the current refugee crisis, which are likely to begin to have a significant effect on funeral practices over the coming decade.

The gradual development of research on the topic of Islam within Europe has focused on many other topics that were of crucial importance for large Muslim

${ }^{6}$ For the general relationship between "institutional," "cultural" and "individual" Muslims in Europe see T. Sakaranaho, Religious Freedom, Multiculturalism, Islam, Leiden 2006, pp. 208-213. For the European context see Muslims in the Enlarged Europe: Religion and Society, B. Maréchal, S. Allievi, F. Dassetto, J. Nielsen (eds.), Leiden 2003. For the German context see M. Rohe, Der Islam in Deutschland: Eine Bestandsaufnahme, Munich 2016.

${ }^{7}$ Other examples are communities of Bosnians or Albanians.

${ }^{8}$ Y. Karakaşoğlu, Die Bestattung von Muslimen in der Bundesrepublik aus der Sicht türkisch-islamischer Organisationen [in:] In fremder Erde..., op.cit., p. 83. 
organisations during the 1990s. Some of the most pressing problems lie in the fields of education (the teaching of Islam in public schools, headscarves worn by Muslim teachers, the exemption of Muslim girls from swimming lessons or school trips etc.), complications associated with the purchase of suitable premises for the establishment of cultural centres or land for the building of representative mosques in the centre of larger cities, ${ }^{9}$ and, last but not least, difficulties associated with the acquisition of permission for the ritual slaughter of animals. In other words, the long-term emphasis has been on the building of mosques and the provision of educational courses and similar activities that, essentially, are aimed at supporting the smooth handover of traditional forms of Islam to future generations.

The increasing number of first-generation Muslims who are now reaching retirement age, along with the previous waves of political asylum seekers who have been arriving in Western Europe, often without plans for an early return, has led to an increased interest in addressing issues connected with the end of life, i.e. Islamic regulations regarding funerals, the operation of cemeteries and, in particular, the compatibility with German and Austrian laws. ${ }^{10}$ This emphasis has also been reflected in international academic discourse, in which researchers from the ranks of lawyers, philosophers and specialists in other scientific disciplines have used their texts to illustrate the current situation and highlight key points. ${ }^{11}$ Given the higher prevalence of municipal cemeteries with a section dedicated to Muslim funerals, considerably more attention has been paid to the so-called old federal states of contemporary Germany (Bavaria, Hesse, North Rhine-Westphalia). However, to fully understand the fundamentals of this issue, it is also necessary to monitor similar situations in Austria and Switzerland. Comparative religious studies, however, go beyond the horizons of German-speaking countries and also address the issue of secular public spaces in France, a solution based on the Dutch concept of the pillarisation of society, as well as multiculturalism in relation to the high number of different ethnic and religious groups in modern-day Britain. ${ }^{12}$ As we shall see in the following paragraphs,

${ }^{9}$ E. Orossová, Bezproblémová výstavba? Mešity Merkez a Zentralmoschee, diskuze klíčových aktérů a integrace muslimů v současném Nèmecku, "Pantheon" 2015, vol. 10, no. 2, pp. 21-36.

${ }^{10}$ For comparison with the Czech society with regard to research of intergroup threats see T. Janků, Islámská funerálni kultura jako konfliktni téma v české společnosti [in:] Sborník z IV. mezinárodni vědecké konference studentů doktorských studijních programů v oblasti společenských věd, T. Hubálek (ed.), Praha 2015, pp. 222-230.

${ }^{11}$ See e.g. M.S. Holland, Muslimische Bestattungsriten und deutsches Friedhofs- und Bestattungsrecht, Potsdam 2015; B. Gartner, Der Islam im religionsneutralen Staat: Die Problematik des muslimischen Kopftuchs in der Schule, des koedukativen Sport- und Schwimmunterrichts, des Gebetsrufs des Muezzins, des Schächtens nach islamischem Ritus, des islamischen Religionsunterrichts und des muslimischen Bestattungswesens in Österreich und Deutschland, Frankfurt 2006; M. Rohe, Der Islam in Deutschland..., op.cit.; R. Sörries, Muslime in deutscher Erde. Sterben, Jenseitserwartung und Bestattung, Kassel 2009; G. Höpp, G. Jonker, In fremder Erde. Zur Geschichte und Gegenwart der islamische Bestattung in Deutschland, Berlin 1996.

${ }^{12}$ See e.g. R. van den Breemer, M. Maussen, On the Viability of State-Church Models: Muslim Burial and Mosque Building in France and the Netherlands, "Journal of Immigrant \& Refugee Studies" 2012, vol. 10, no. 3, pp. 279-298; C. Venhorst, Muslims Ritualising Death in the Netherlands, Berlin 2013; S. Firth, Cross-cultural Perspectives on Bereavement [in:] Death, Dying and Bereavement, D. Dickenson, M. Johnson, J.S. Katz (eds.), London 2000, pp. 338-346. 
if we shift our focus away from specific situations associated with the integration of Muslims, the results emanating from existing research can be compared to situations concerning other religious, ethnic, ideological and interest groups in society.

\section{Transport of deceased persons back to the country of their origin}

Attempts to more precisely estimate the number of Muslims living in today's Germany were a matter of professional discourse long before the refugee crisis of 2015. If we accept the latest official information from the Federal Office for Migration and Refugees, the estimate is between 4.4 and 4.7 million, and, importantly for the focus of this paper, about half of them have German citizenship. ${ }^{13}$ Asiye Balıkç1-Schmidt estimates that among the Muslims living in Germany, regardless of their affiliation to a particular branch, there are approximately 30,000 deaths each year. ${ }^{14}$ According to the Institute for Islamic Studies at the University of Vienna, there are over 580,000 Muslims living in Austria, and over 200,000 have Austrian citizenship. Annually, there are approximately 5,700 deaths. ${ }^{15}$

In connection with these numbers, it should be noted that in both countries a longterm trend has been established over the past few decades by which dead bodies are transported to their original homeland, with about $90-95 \%$ being transported back to their country of origin. Most of the relevant academic literature confirms this information, but in the case of Germany it is still only an estimate because of the lack of results from any level of systematic research at the federal level. ${ }^{16}$ Examining the arguments of the first generation of Muslims living in Germany and Austria, such data can be associated with the so-called myth of return, ${ }^{17}$ which is very strong in this section of Muslim society. The feeling of not being grounded and of the temporary nature of their stay in the countries of "foreign" Western Europe persists among the eldest members of the family with regard to their individual migration history, and this leads to their decision to have the funeral rites performed in the original homeland. However, even with some members of the second generation of migrants, some concerns remain as to the proper procedures associated with the actual burial in relation to Islamic law (ritual cleansing, coffin use, etc.). As we shall see, another key issue often comes with securing a permanent resting place for the deceased and

${ }_{13}$ A. Stichs, Wie viele Muslime leben in Deutschland?, Nuremberg 2016, p. 5.

${ }^{14}$ A. Balıçı, Integration auf dem Friedhof - Muslime in Köln und Essen, "Friedhofskultur Zeitschrift für das gesamte Friedhofswesen" 2011, vol. 101, no. 7, p. 21.

15 J. Kolb, B. Mattausch-Y1ld1z, Muslimische Alltagspraxis in Österreich, Vienna 2014, pp. 20-21.

${ }_{16}$ T. Blach, Nach Mekka gewandt. Zum Umgang türkischer Muslime mit ihren Verstorbenen in der Türkei und in Deutschland, Kassel 1996, pp. 54-56; M.S. Holland, op.cit., p. 15; S. Heine, R. Lohlker, R. Potz, Muslime in Österreich. Geschichte, Lebenswelt, Religion. Grundlagen für den Dialog, Innsbruck 2012, p. 134.

${ }_{17}$ D. Tan, Wandlungen des Sterbens und der Trauerrituale in der Migration [in:] In fremder Erde..., op.cit., pp. 126-127; Y. Chaïb, Der Status des Todes in der Migration [in:] In fremder Erde..., op.cit., p. 154. 
associated problems regarding the temporary lease of burial sites and their reuse in German and Austrian municipal cemeteries.

The act of transporting the bodies of mostly foreign nationals abroad has for a long time, at least on the part of local Islamic organisations, been conducted in a piecemeal manner in cooperation with other agencies, such as the Turkish embassy and regional consulates. Since the early days, an important issue has always been the procurement of the financial resources needed for the transport of bodies to their original homeland, which still remains an expensive choice. ${ }^{18}$ To address this challenge, many Muslim communities, as is the case with other groups, have traditionally followed a system where the required amount is paid on a case-by-case basis and funded by the donations of believers.

As a result of the gradual institutionalisation of the entire process during the first half of the 1990s, technical solutions have in practice been established, and these have been proven to be successful in spite of subsequent developments. We should mention here professional funeral companies serving the needs of Muslim clientele, the emphasis on the speed of implementation and on the continuity of procedures when handling the body, as well as when dealing with the associated bureaucracy and administrative issues. This has helped to reduce the percentage of problem cases to a minimum (e.g. difficulties still exist in relation to a deceased person without a family). The entire process, beginning with the collection of the body from the family environment in Western Europe, followed by its burial, mainly in Turkey, Bosnia or Morocco, and ending with the organisation of funeral and memorial ceremonies in Germany and Austria, can also be viewed critically. Concerns arise not only from a religious perspective, which draws attention to the unnecessarily long period of time between death and burial. This breakdown of the "unity of space and time," according to the sociologist Dursun Tan, is also frustrating for the family, and undermines its ability to integrate..$^{19}$ As for securing the financial resources required for transportation, special funeral funds were set up in rapid succession within large Muslim organisations for this very purpose. The purpose of their work is to assume the cost and financial risk associated with this process, with the necessary amount being funded from the regular payments made by association members. ${ }^{20}$

As with Muslim organisations in general, two interesting issues emerge specifically in relation to funeral services. The institutionalisation of the funeral process has benefitted a number of actors. For example, it has created a functioning infrastructure of experts who are able to assist believers during these difficult times, and in addition there are benefits for the municipalities, with the owners and operators of cemeteries welcoming these experts as communication partners. ${ }^{21}$ However, if we look at the whole issue from the perspective of the belief that a funeral in Germany or Austria

${ }^{18}$ T. Blach, op.cit., pp. 60-61.

19 D. Tan, op.cit., p. 121.

${ }_{20}$ T. Lemmen, Islamische Organisationen in Deutschland, Bonn 2000, p. 38; Y. Karakaşoğlu, op.cit., p. 88; H. Yildiz, Muslimische Sterbekassen in Deutschland [in:] Muslime in deutscher Erde. Sterben, Jenseitserwartung und Bestattung, R. Sörries (ed.), Kassel 2009, pp. 65-68.

${ }^{21}$ M. Klapetek, Muslimské organizace..., op.cit., p. 51. 
is an indicator of integration, then paradoxically, the past two decades, dedicated to enhancing the effectiveness of institutions arranging the repatriation of bodies, have been counterproductive. There has in fact been no significant reduction in the number of bodies being transported to their country of origin, despite the fact that the funds provide only partial financial support, even in cases where the funeral takes place in Germany and Austria. ${ }^{22}$

\section{Burial in a new homeland}

The proportion of Muslim funerals that take place in the surveyed countries is still very low when compared to the numbers of bodies transported abroad, and this will probably continue to slowly rise. One of the traditional focal points of academic discourse is the identification of the specific groups being buried in Germany and Austria. The high numbers associated with the burial of new-born babies and young children can be seen as an indicator of future change. In the 1970s, $90 \%$ of funerals fell into this category, but twenty years later the ratio of children to adults had become more equal. ${ }^{23}$ During this period we can observe the development of a relatively pragmatic approach to the burial of young children in Europe, a trend that became even more pronounced as a result of the efforts of financially weaker families to raise the necessary funds to transport the bodies of deceased adults to their countries of origin. The burial of second-generation Muslim children living in Germany seems to represent an important shift in relation to local funeral culture. ${ }^{24}$ Experts agree that the burial of a young child in the new homeland serves to strengthen the bonds of the parents and extended family to the local environment, regardless of their citizenship. The results of my research in relation to the establishment of designated Muslim areas in German and Austrian municipal cemeteries, however, confirm the conclusion that the integration potential of the funerals of young children thus defined is not automatic in all cases, and can often be only temporary. ${ }^{25}$

${ }^{22}$ I thank the reviewer for the comments. In Wuppertal, a cemetery owned by Muslims is to be opened. The good cooperation between Muslim communities and the local authorities in Fulda also increases the interest in having a burial in Germany. These cases demonstrates the active attitude to solve this problem.

${ }^{23}$ G. Kokkelink, Islamische Bestattung auf kommunalen Friedhöfen [in:] In fremder Erde..., op.cit., p. 64.

${ }^{24}$ Y. Karakaşoğlu, op.cit., pp. 98, 102; Y. Chaïb, Der Status des Todes in der Migration [in:] In fremder Erde. Zur Geschichte und Gegenwart der islamischen Bestattung in Deutschland, G. Höpp, J. Gerdien (eds.), Berlin 1996, p. 150.

${ }^{25}$ We can compare the level of maintenance of young children's graves built at Parkfriedhof Heiligenstock, Frankfurt, in the years 2013 and 2014. According to the non-participant observation held in 2015 , there are many variants, from no maintenance to regular and thorough maintenance. The resulting situation is influenced by both the normative form and the cultural interpretation of religion. But it is necessary to compare this type of observation with the results of interviews with family members. Thorsten Blach did just this, interviewing Turkish mothers from Munich in the mid-1990s. Some women loses their relationship with the deceased child afterwards. Life goes on, another baby may born and the deceased child is often with them for a very short time. T. Blach, op.cit., pp. 73-82. 
Other groups include: Muslim converts with German or Austrian nationality; followers of Islam with German or Austrian life partners; war refugees; and politically persecuted persons who are entitled to asylum. Finally, there are various problematic cases, which may include victims of violence (murder in the family, heavily damaged corpse due to a car accident, etc.), or situations where the deceased was buried without the existence of family ties. ${ }^{26}$

The most common choice of solution to the specific requirement for individuals in non-Muslim environments to be buried in accordance with Islamic rites has been the establishment of special areas of cemeteries. These areas are mostly in municipal cemeteries, with one of the Christian churches being the landowner in some cases. It is estimated that there are currently two hundred such areas in Germany, and that this method of organisation is used in about ten locations in Austria. ${ }^{27}$ Their location indicates that the primary concentrations of Muslims are in metropolitan areas of the federal states and in other major industrial centres, such as the cities of North RhineWestphalia. ${ }^{28}$ We can refer to the historical context when defining the three main periods during which these areas were established in Germany. The first category includes the specific example of Hamburg-Ohlsdorf, where the so-called Islam-Mohammedan cemetery was created as early as 1941 , and thus cannot be automatically regarded as being caused by later economic migration. The area was developed in response to the needs of the local community of Iranian traders and, thanks to the colourful variety of its tombstones, remains a very interesting site. The second period can be pinpointed to the Second World War, when several areas were established for Muslims, mostly from Eastern Europe and the Balkans, ${ }^{29}$ in the federal state of Bavaria (e.g. the Forest Cemetery in Munich in 1955 and later in Neu-Ulm and Forchheim). Numbers often included prisoners of war who, for various reasons, did not want to (or could not) return to their original homeland, and remained in southern Germany. The third period, from the 1960s onwards, has been characterised by the establishment of special cemeteries for Muslims, as a direct result of mass economic migration events. These include the cities of the Ruhr valley (Düsseldorf in 1963, followed by the Western cemetery in Cologne in 1965)..$^{30}$ Other solutions can be considered as important exceptions that confirmed the trend prevailing in both countries. This category includes the management of Berlin's famous Cemetery of Martyrs on Columbiadamm by the Turkish embassy, based on a previous historical development, and, in the case of

${ }^{26}$ B. Gartner, Der Islam im religionsneutralen Staat..., op.cit., pp. 264-266. Generally on this issue see K. Orszulak-Dudkowska, Przestrzeń cmentarza w historii kultury europejskiej [in:] Ars moriendi, ars vivendi, ars educandi, Z. Rudnicki (ed.), Poznań 2012, pp. 369-388.

${ }^{27}$ M. Klapetek, Umírání a smrt: Realizace náboženských pravidel v nemuslimském prostředí [in:] Smrt, hroby a záhrobi v islámu. Posledni věci člověka pohledem muslimských pramenư, B. Ostřanský (ed.), Praha 2014, p. 254; S. Heine, R. Lohlker, R. Potz, op.cit., p. 134 (for example Vienna, Graz, Innsbruck, Klagenfurt, Linz, Salzburg or Telfs). In other cities, there are at least a few graves which are not placed in a special area for Muslims in general.

${ }^{28}$ A. Morgenroth, F. Lauritzen, Chancen für das deutsche Friedhofswesen, "Friedhofskultur Zeitschrift für das gesamte Friedhofswesen" 2011, vol. 101, no. 7, pp. 25-27.

${ }^{29}$ I thank the reviewer for the comment. In southwestern Germany, Muslims' graves can be found at cemeteries for soldiers, in particular French ones from North Africa and Senegal.

${ }^{30}$ R. Sörries, Von Mekka bis Berlin..., op.cit., p. 146. 
Austria, the commissioning of the Muslim area of the so-called Interconfessional Cemetery in Graz in 2007, or the establishment of a large Islamic cemetery in Vienna-Liesing in 2009, along with the opening of the Islamic cemetery in Altach in 2012 (Vorarlberg), which has been highly praised by architects.

In order to understand the current situation it is necessary to be clear about the exact definition of terms such as founder, owner, and operator of a public cemetery. Most frequently, these roles are fulfilled by local boroughs, Christian churches and Jewish communities, because they are the holders of the required public rights. To be precise, at the federal level in Germany there is no Islamic association with the status of a corporation with public rights (Körperschaft des öffentlichen Rechts). ${ }^{31}$ In the case of the federal states of Berlin and North Rhine-Westphalia, even now it is possible to find alternative legal solutions which would theoretically allow for the involvement of local Muslim communities in the management of public cemeteries. ${ }^{32}$ However, in practice, this has not yet been implemented because of the high costs involved in such a project, a consideration that plays a significant role in the establishment of public or private cemeteries.

With regard to the different legal situations stemming from the historical contexts of the nineteenth and twentieth centuries, it should be noted that in Austria, apart from the option to create separate areas for Muslims in municipal cemeteries mentioned above, there are currently two additional potential solutions. The first example is the Islamic cemetery in Vienna's Liesing district, which is owned by the Islamische Glaubensgemeinschaft in Österreich. It is a state-recognised religious association which has public rights. ${ }^{33}$ Unlike this cemetery, which was created specifically for Muslims and managed by them, the Islamic Cemetery in Altach is jointly owned by various municipalities, which established and manage it. The main objective was to ensure that any Muslim from the towns and municipalities of this federal state could be buried here, regardless of his or her membership in any umbrella organisation. This leads us to an ongoing discourse which is currently discussed in other countries of Western Europe. One solution to the current situation is the designation of a general "Islamic" area/cemetery. Another one is the establishment of clearly differentiated separate sections, according to a particular school of Islam (e.g. Sunni, Shi'ah, Ghulat) or a person's nationality (e.g. Turkish, Egyptian, Pakistani, Bosnian, Iranian, etc.).

In Germany, the basic legal framework that affects the creation and operation of specialised areas in municipal cemeteries for Muslims is the Basic Law of the Federal Republic of Germany (Grundgesetz für die Bundesrepublik Deutschland, ${ }^{34} \mathrm{GG}$ ). Furthermore, there are other laws relating to funeral services which conform to Article 30 and are within the competency of individual federal states. This has resulted in completely different solutions to similar problems related to funeral arrangements

${ }^{31}$ A marginal exception is the Ahmadiyya Muslim Jamaat, which acquired this status in 2013 in Hesse and in 2014 in Hamburg.

${ }^{32}$ M.S. Holland, op.cit., pp. 58-59. An Islamic cemetery project in Wuppertal is close to completion.

33 M. Klapetek, Muslimské organizace..., op.cit., pp. 144-147.

${ }^{34}$ Grundgesetz für die Bundesrepublik Deutschland vom 23. Mai 1949 (BGBl. I, 1), zuletzt geändert durch Artikel 1 des Gesetzes vom 11. Juli 2012 (BGB1. I 2012, 1478). 
in contemporary Germany. ${ }^{35}$ The situation in neighbouring Austria is very similar in this respect. ${ }^{36}$ To clarify the position in both countries, however, it is necessary to consider the issue from the perspective of the owners, and usually also the operators, of cemeteries. They manage the legal relationship between the founder of the cemetery (e.g. the village, the church) and its users (e.g. the people who have rented space in the cemetery) and do so by the issuance of cemetery regulations. Generally speaking, the aim of the cemetery regulations is to ensure the smooth operation of funeral ceremonies and of cemetery management while maintaining the dignity associated with a place of rest. Cemetery regulations may vary in their detail, depending on what is allowed or prohibited according to the legal regulations at the state level. A classic example is the explicit rule stating the necessity of being buried in a coffin, ${ }^{37}$ which is accompanied by provisions relating to the lease of burial space and to the extension of the lease period beyond the period of decay. This often varies depending not only on the type of grave (terraced grave, tomb), but also on the local soil conditions, the groundwater level etc., which must also be taken into account. It is within these cemetery regulations that we can clearly see both the results of the complicated debates aimed at protecting local cultural, religious, and worldview values in the face of anticipated threats, in this case from "Islam," but also the very practical problems related to environmental protection etc. ${ }^{38}$

\section{Supradenominational management of cemetery versus the establishment of special areas?}

An analysis of the research on areas designated for Muslims in German and Austrian municipal cemeteries takes us from the theoretical and legal introductory framework to specific aspects of implementation. As with mosques and Islamic cultural centres located in public spaces, the so-called cemeteries within cemeteries ${ }^{39}$ are the result of dialogue between more generally designed laws and local ordinances and the need to fulfil specific religious requirements in a non-Muslim environment.

${ }^{35}$ An example is Lower Saxony. F. Vladi, Sterben, Jenseitserwartung und Bestattung - Muslime in deutscher Erde [in:] Muslime in deutscher Erde..., op.cit., pp. 29-36.

${ }^{36}$ Funeral services are managed by federal states (article 15; article 10, paragraph 1, no. 12 of Austrian Federal Constitution). Enforcement of these rights is the responsibility of local municipalities (article 118, paragraph 2 and 3, no. 7 of Austrian Federal Constitution). B. Gartner, Das islamische Bestattungswesen [in:] Islam in Österreich, A. Janda, M. Vogl (eds.), Vienna 2010, p. 50. I thank the reviewer for the comments. In Austria, the relationship between government and Muslims is dealt with at the federal level (Islamgesetz 2015), but in Germany, it is dealt with at Land level.

${ }_{37}$ T. Lemmen, Muslimische Grabfelder in Deutschland [in:] Sunna leben. Zur Dynamik islamischer Religionspraxis in Deutschland, P. Schrode, U. Simon (eds.), Würzburg 2012, pp. 95-96. For example, the laws of North Rhine-Westphalia delegate this decision to the particular owner of the cemetery, who prescribes burial in a coffin or not.

${ }^{38}$ R. Hartmann, H. Kijewski, Grundwasser- und bodenhygienische Aspekte der Leichenzersetzung mit bzw. ohne Sarg [in:] Muslime in deutscher Erde. Sterben, Jenseitserwartung und Bestattung, R. Sörries (ed.), Kassel 2009, pp. 81-88.

${ }^{39}$ R. Sörries, Von Mekka bis Berlin..., op.cit., pp. 150, 157. 
We can consider the issue of Muslim funeral culture through the acculturation process (in this case, mainly assimilation, integration, and separation). In the author's opinion, one of the key themes is the emphasis on spatial separation from other diversely defined population groups. At first glance, this may seem to be a simple matter. ${ }^{40}$ When Muslims require an area designated specifically for them on the basis of religion, this certainly does not suggest assimilation. The question is whether such cases are always essentially about social separation. Based on a comparison with other specific groups in contemporary German and Austrian society, it is indeed possible to assert that even requests for specific space within a municipal cemetery can still be regarded, in connection with the natural diversity within society, as an integration theme.

At this point we should note that the supradenominational management approach adopted by cemeteries was not typical in Europe until after the nineteenth century. Prior to this, the final resting place issue had largely been subject to a strict differentiation, based primarily on the principle of denomination (Catholic, Protestant, and Jewish cemeteries). The current approach to cemetery governance in large German and Austrian cities is naturally based on the principles defined in the nineteenth century; however, with respect to later social developments, we can observe concrete refinements of the traditional general principles of neutrality and supradenomination. ${ }^{41}$ The shapes of last resting places reflect the changes in society with regard to its religious as well as non-religious profile. Such changes can be observed through the establishment of designated burial areas.

On the one hand, the various special burial areas within a municipal cemetery might be defined according to the type of funeral, which may include, for example, the provision of an urn grave or the existence of anonymous graves. ${ }^{42}$ This is a theme which is also important in relation to Islamic funeral culture, because it includes requirements related to the banning of cremation, the different orientation of graves, a preference for burials without coffins, the maintenance-free design of graves and an extension of the lease period. On the other hand, groups of graves are formed in these special areas. People belonging to a defined community or group of people were buried in such graves.

From an acculturation perspective, supported by subsequent research into this phenomenon, two basic models emerge. The first one is associated with the prevailing characteristics of integration, and occurs in a particular municipal cemetery where there are clearly defined special areas, based, for example, on affiliation with a religious or philosophical community ${ }^{43}$ Even in the latter case, however, completely new and separate units can be found. The city of Hamburg provides us with one

${ }^{40}$ Similarly, the hypothesis that assimilated groups of Muslims prefer modern forms of mosques has been disproved. E. Roose, The Myth of the Orientalist Mosque. Towards an Iconography of Islamic Architecture in the Netherlands, "Canadian Journal of Netherlandic Studies" 2012/2013, no. 2/1, pp. 83-106.

${ }^{41}$ I thank the reviewer for the comments. This redefining of cemetery governance was highly influenced by industrialisation, urbanisation and secularisation.

42 T. Lemmen, Muslimische Grabfelder..., op.cit., p. 90.

${ }^{43}$ The example is the Vienna Central Cemetery, which is administrated supradenominationally, but there is a wide range of special areas assigned to people of particular religious affiliations (Buddhists, Muslims, Mormons, etc.) or worldviews (the forest cemetery with an emphasis on ecology). Another 
such example. In the 1990s, a cemetery was established exclusively for victims of the AIDS epidemic. In 2008, a designated last resting place for fans from a particular football club was established. Reiner Sörries refers to such developments as "clan cemeteries." The basic concept is one of burial based on one's affiliation to a certain group of like-minded people, and according to Sörries, this is an important theme when describing a so-called multicultural cemetery. The identity of these people does not have to be defined exclusively through reference to their own family. They may also be part of a community of their choice (e.g. a sports fan club), groups with religious or philosophical beliefs (solution based on denomination), or a community formed on the basis of the same fate (carriers of the HIV virus). ${ }^{44}$

\section{Areas in cemeteries as a subject of Muslim community research}

It is very interesting to observe the specific choice of location for specially designated Muslim areas within municipal cemeteries and their relationship with other parts of the site. Such an analysis also brings to light the fact that municipal cemeteries are built on the outskirts ${ }^{45}$ of cities in German and Austrian federal states, in many cases as a result of the grand planning schemes of the nineteenth century. If built at a later time, they more or less replicate the core elements of earlier designs. With reference to the general layout of such cemeteries, there is an invariable dichotomy between the central part of the site, with its main avenue, honorary graves and, frequently, a sacral building functioning as a place of farewell, and the periphery on the edges of the cemetery. ${ }^{46}$ The choice of final resting place permanently defined the status of the deceased within a hierarchical society.

With regard to the choice of location for the Islamic burial area, a general preference for the central part of the cemetery complex might not necessarily always apply. The choice was also influenced by the historical context of the second half of the twentieth century, with Islamic areas being one of the last additions to appear in a number of German and Austrian cemeteries, frequently occupied by only a small number of graves in the short term. The choice of a peripheral area for Muslim burials might also have been welcomed by the community itself, which would thus have been able to emphasise its distance from the surrounding non-Muslim graves, in addition to the planting of trees along the already designated pathways. Another important issue was the need to ensure that the burial took place in soil which had never previously been used for a burial, as well as attempts to delay the possible cancellation of so-called terraced graves after the expiry of their lease so as to ensure the

specific example is the Humanist funeral grave in the Forest Cemetery in Berlin-Zehlendorf, designed for people who find the local supradenominational cemetery not neutral enough.

${ }^{44}$ R. Sörries, Der Trend zum multikulturellen Friedhof in Deutschland [in:] Muslime in deutscher Erde..., op.cit., pp. 13-15.

${ }^{45}$ K. Orszulak-Dudkowska, op.cit., p. 373.

46 This dichotomy also appears in the research on conditions affecting the location of new mosques. M. Klapetek, Mešita v 'zadním dvoře', "Nový Orient” 2015, vol. 70, no. 1, pp. 2-9. 
permanency of the final resting place for the deceased, as required by Islam. ${ }^{47}$ Finally, it is necessary to look at the whole issue from the perspective of the administrator of the cemetery, as this was one of the major actors influencing the final layout of the cemetery. The administrator was keen for the less popular areas on the periphery to be better utilised. Another important factor was that some of the Muslim graves, even after the period of mourning, were furnished with minimalist tombstones and, for religious reasons, were not later maintained to the same extent as was common for the surrounding non-Muslim graves. Thus, these graves were not as visible to other cemetery visitors and did not impair the overall aesthetic appearance. This, among other things, meant that it was possible to avoid complaints that some of the requirements specified in cemetery regulations were being violated..$^{48}$

When studying the establishment of special burial areas designated for Muslims, it is necessary to consider not only the external relationship with neighbouring units in cemeteries that operated supradenominationally, but also the possible internal stratification of these areas. In other words, the question remains as to what influences the designation of the burial area as "Muslim/Islamic" with regard to the different currents within Islam and the relationship with other religious and ethnic groups (e.g. Baha'i, Druze, Yazidi). ${ }^{49}$ Irrespective of whether we are referring to large European cities or other contexts, an issue that always arises is whether a new burial area is intended to be used by all Muslims without exception, or whether it is necessary to ensure additional segregation. ${ }^{50}$ There is still the overall requirement to be buried "among Muslims," and this issue reflects the internal tensions that exist between various strands of Islam. On the one hand, by disregarding this requirement for differentiation between various Islamic groups in relation to burial, there is a tendency for some Muslims to choose to transport the body of the deceased to their country of origin. On the other hand, there are examples where, as a result of an agreement between local Islamic communities, only one space is designated within the municipal cemetery. ${ }^{51}$

In the author's opinion, as is the case in relation to the building of mosques and prayer rooms, there is an element of competition between various groups within organised Islam in Germany and Austria. Islamic associations are often engaged by the operator of a cemetery to act as consultants in relation to the creation and subsequent use of burial areas. Even in the Western European environment, separate mosque associations

${ }^{47}$ L. Jennerich, Islamische Grabfelder in Deutschland, "Friedhofskultur - Zeitschrift für das gesamte Friedhofswesen" 2000, vol. 100, no. 6, pp. 20-23.

${ }^{48}$ G. Kokkelink, op.cit., p. 66. I thank the reviewer for the comments. The general customs influenced the Muslim practices in Austria and Germany, which can be demonstrated with regard to two aspects of graves. Firstly, the form of gravestone has changed; some of them have become closer to the graves of general customs. Furthermore we can find graves which are decorated with planted flowers and regularly taken care of.

${ }^{49}$ R. Benninghaus, Friedhöfe als Quellen für Fragen des Kulturwandels: Grabkultur von Yeziden und Aleviten in Deutschland mit Seitenblick auf die Türkei [in:] Migration und Ritualtransfer: Religiöse Praxis der Aleviten, Jesiden und Nusairier zwischen Vorderem Orient und Westeuropa, R. Langer, R. Motika, M. Ursinus (eds.), Frankfurt 2005, pp. 247-288.

50 A. Balıkçı, op.cit., p. 23.

${ }^{51}$ The example from abroad is Amsterdam. R. van den Breemer, M. Maussen, op.cit., p. 286. 
and the local branches of organisations operating at a federal level often retain certain characteristics which stem from the ethnic, religious and, in particular, political contexts associated with their country of origin. However, this preservation of tradition is not only a specific programme promoted by the leadership of an organisation. The membership base also needs a number of important religious and cultural elements that constitutes their identity. This can be observed in relation to the disputed influence of some Muslim communities in Europe on the modern appearance of contemporary mosques, including the potential for assimilation. ${ }^{52}$ Similarly, in the case of burial areas, we can trace the links between traditional forms of graves (the use of two stelae, the low levels of maintenance of the surface) and the influence of the forms of neighbouring gravestones used in German and Austrian cemeteries (the use of more expensive materials, photographs of the deceased as a fixed part of the installation, regularly replaced flowers and plants). The decisive factor in such cases remains the specific preferences of the family, which may or may not reflect the wishes of the deceased or the normative views advocated by, primarily, the representatives of their religious community. In other words, because Islamic organisations in Germany cannot under the present conditions become the owners of public cemeteries, their influence on the relationship between the municipality and the person renting the burial place is limited.

However, there is one area in which the organisations have a clear role that enables them to exert an influence beyond the level of the individual grave. This is in relation to the establishment of special areas or buildings within the Muslim section of the cemetery which can be used during the preparation of the body for its final journey, as a space where prayers can be said for the deceased, or during the actual funeral. Essentially, these are special spaces where the ritual washing of the body and its wrapping in a funeral shroud can be undertaken, ${ }^{53}$ and these activities are attended by representatives of the survivors and conducted by professional staff from Muslim funeral service organisations. In some cases, these activities are carried out by an authorised person from volunteers engaged in diverse mosque-related work, acting in cooperation with the operator of the municipal cemetery. Another traditional requirement, which is dealt with in cooperation with religious specialists from local mosque groups, is the provision of suitable premises within the area of the cemetery for the coming together of the congregation of mourners. There is often a problem associated with the insufficient size of the funeral hall and also in relation to its decoration with the symbols of other religions (the result of the aforementioned supradenominational operation of cemeteries). There are also difficulties associated with the performance of collective prayers for the deceased, usually in the open air, as it is necessary to find

${ }^{52}$ E. Roose, Mosque Design and Muslim Patrons in the Netherland. The Quest for the Ultimate Islamic Construction [in:] The Mosque: Political, Architectural and Social Transformations, E. Erkoçu, C. Buğdacı (eds.), Rotterdam 2009, p. 116.

${ }^{53}$ In Berlin in 2010, legislation was implemented on the ritual washing of the corpse. This ritual washing can be done only in a morgue or in religious institutions that have been authorised by the district authorities in accordance with the relevant sanitary measures ( $\$ 10$ a Rituelle Waschungen von Leichen Gesetz über das Leichen- und Bestattungswesen). In other federal states, the relevant legal measures for the handling of bodies must be respected. 
a suitable location near the building ${ }^{54}$ that provides for the typically high number of participants in the ceremony and also takes into account the possible effects of adverse weather conditions. At first glance, this may seem to represent only a marginal issue, but this is not always the case. For many Muslims, securing a suitable space for the performance of funeral rituals is far more important than the issue of visiting the grave in the future. ${ }^{55}$ One possible solution is to build a special structure, right on the edge of the burial area, equipped with running water for ritual purification purposes and a table on which the coffin containing the corpse can be placed during the collective prayers for the deceased. ${ }^{56}$

\section{Conclusion}

Previous research into matters associated with Islamic funeral culture pointed to important changes that took place during the first half of the 1990s, a time when funeral funds were being established and operated by prominent religious organisations. As a result of their success, the original temporary solutions to the challenges became permanent features. The vast majority of the deceased are still transported back to their country of origin and, consequently, this prevents successful integration. With regard to the establishment and operation of specialised areas within municipal cemeteries, the significance of the process of institutionalisation has become clear (the influence of the leadership of mosque groups), and so has the emphasis on expert solutions (funeral services tailored to meet the needs of Muslim clients).

Religionists and sociologists expect there to be future increases in the number of Muslim burials in Western Europe. This is clearly the case in relation to the population groups ${ }^{57}$ who are buried locally as a result of their individual circumstances and family situation. Specific importance is also attached to the funerals of newborns and young children, but the long-term integration effect of such funerals on the whole family is still debatable. Future developments associated with the establishment, ownership and operation of Islamic cemeteries in Germany are currently constrained by the problems associated with the historical failure of the state to confer

${ }^{54}$ A suitable place is also searched for in the case that the prayer takes place outside the mosque in the city and the funeral rituals are finished in the cemetery. T. Lemmen, Muslimische Grabfelder in Deutschland..., op.cit., p. 94. In the Berlin-Neukölln district, the burial rituals often take place in the suitably adapted neighbourhood of the mosque standing at the Cemetery of Martyrs on Columbiadamm, even if the deceased is ultimately buried at the remote Landschaftsfriedhof Gatow in the Berlin-Spandau district. R. Sörries, Von Mekka bis Berlin..., op.cit., p. 144.

55 M. Klapetek, Umírání a smrt..., op.cit., pp. 277-278; J. Malecká, Narození, svatba a pohřeb v sunnitském islámu, Brno 2014, pp. 201-204.

56 S. Lohmann, Mit Blick gen Mekka, "Friedhofskultur - Zeitschrift für das gesamte Friedhofswesen" 2011, vol. 101, no. 7, pp. 28-29. In the Central Cemetery in Vienna, the stone coffin table used during the prayers for the dead is located on the edge of field no. 36, and a mihrab is built in field no. 27 , which is surrounded by evergreen bushes.

57 Muslim converts with German or Austrian nationality, followers of Islam with German or Austrian life partners, war refugees, and politically persecuted persons who are entitled to asylum etc. 
public rights on prominent local Muslim organisations. ${ }^{58}$ Neighbouring Austria has already initiated several successful solutions that have been described as forms of integration by both experts and the representatives of Islamic groups. ${ }^{59}$ The current situation is influenced by the need to respond to an ever increasing number of people from the first generation of Muslim migrants who are now advanced in years, but also by the phenomenon of asylum seekers who, in the coming years, will not be able to return to their homelands. In the next decade, however, the focus will shift towards the second and third generations of people, i.e. those who have spent most of their lives in Germany or Austria or who were born there. An important element here is the extent to which these cohorts will draw nearer to the culture of the mainstream society (integration), particularly in relation to the number of children they have and their preferred lifestyle, possibly even adopting this culture to a significant degree (assimilation). ${ }^{60}$ Another important topic for further research will be the demographic transformation of contemporary Germany and Austria, particularly in relation to their affiliation to Islam and to future waves of migrants. Important in this respect will be the level of religiosity and religious practice. Last but not least, it will be necessary to reflect conversions of born-Muslims out of Islam, especially to Christianity. ${ }^{61}$

When making comparisons with other cases from contemporary Germany and Austria, it becomes clear that the creation of special areas within supradenominationally managed cemeteries may not actually constitute an expression of separation. On the contrary, it corresponds to the process of integration within a stratified society. With regard to this process it can be assumed that the forms of Islamic funerals, which are part of a diverse and living culture, will change as they adapt to the new environment. In such an environment, the practices not only confront each other but also respond to the funeral customs of the surrounding non-Muslim society. It will then be possible to expand research initiatives that currently focus on the designation of special Muslim areas in municipal cemeteries to include studies on the application of Islamic burial rites in non-Muslim environments in the funeral ceremony (the preparation of the body, the funeral process, the period of mourning) and, in particular, the grave as the basic unit (the design of tombstones, subsequent visits to the grave, the maintenance of the burial site, time limits associated with the rent). ${ }^{62}$

${ }^{58}$ I thank the reviewer for the comments. The Muslim organisations have to apply some legal requirements; especially they must have existed for at least 30 years.

${ }^{59}$ On the one hand, Muslim organisations' involvement in this process should increase the number of deceased buried in Western Europe with regard to the expected integration potential. On the other hand, it should strengthen control mechanisms of Islamic organisations and lead to stronger competition among strands within Islam.

${ }^{60}$ The ageing of population, emphasis on consumption, lower number of children, singles, leaving the model of strong patriarchal families, the form of contact with the country of the ancestors' origin ("wedding tourism") etc.

${ }^{61}$ I thank the reviewer for the comments.

${ }^{62}$ Muslim cemeteries and burial practices have already been the subject of the German Islam Conference, and continue to be discussed. Deutsche Islam Konferenz, Drei Jahre Deutsche Islam Konferez (DIK) 2006-2009. Muslime in Deutschland - deutsche Muslime, Berlin 2009, pp. 38-41. 


\section{References}

Balıkçı A., Integration auf dem Friedhof - Muslime in Köln und Essen, "Friedhofskultur Zeitschrift für das gesamte Friedhofswesen" 2011, vol. 101, no. 7, pp. 21-24.

Benninghaus R., Friedhöfe als Quellen für Fragen des Kulturwandels: Grabkultur von Yeziden und Aleviten in Deutschland mit Seitenblick auf die Türkei [in:] Migration und Ritualtransfer: Religiöse Praxis der Aleviten, Jesiden und Nusairier zwischen Vorderem Orient und Westeuropa, R. Langer, R. Motika, M. Ursinus (eds.), Frankfurt 2005, pp. 247-288.

Blach T., Nach Mekka gewandt. Zum Umgang türkischer Muslime mit ihren Verstorbenen in der Türkei und in Deutschland, Kassel 1996.

Breemer R. van den, Maussen M., On the Viability of State-Church Models: Muslim Burial and Mosque Building in France and the Netherlands, "Journal of Immigrant \& Refugee Studies" 2012, vol. 10, no. 3, pp. 279-298.

Chaïb Y., Der Status des Todes in der Migration [in:] In fremder Erde. Zur Geschichte und Gegenwart der islamischen Bestattung in Deutschland, G. Höpp, J. Gerdien (eds.), Berlin 1996, pp. 147-149.

Drei Jahre Deutsche Islam Konferenz (DIK) 2006-2009. Muslime in Deutschland - deutsche Muslime, Berlin 2009.

Eisingerich A., Tod als Rückkehr zur Gott, der Quelle allen Lebens - Sterben, Tod und Trauer im Islam [in:] Aller Einkehr ist der Tod. Interreligiöse Zugänge zu Sterben, Tod und Trauer, B. Heller (ed.), Freiburg im Breisgau 2003, pp. 118-143.

Firth S., Cross-cultural Perspectives on Bereavement [in:] Death, Dying and Bereavement, D. Dickenson, M. Johnson, J.S. Katz (eds.), London 2000, pp. 338-346.

Gartner B., Das islamische Bestattungswesen [in:] Islam in Österreich, A. Janda, M. Vogl (eds.), Vienna 2010, pp. 50-52.

Gartner B., Der Islam im religionsneutralen Staat: Die Problematik des muslimischen Kopftuchs in der Schule, des koedukativen Sport- und Schwimmunterrichts, des Gebetsrufs des Muezzins, des Schächtens nach islamischem Ritus, des islamischen Religionsunterrichts und des muslimischen Bestattungswesens in Österreich und Deutschland, Frankfurt 2006.

Hartmann R., Kijewski H., Grundwasser- und bodenhygienische Aspekte der Leichenzersetzung mit bzw. ohne Sarg [in:] Muslime in deutscher Erde. Sterben, Jenseitserwartung und Bestattung, R. Sörries (ed.), Kassel 2009, pp. 81-88.

Heine S., Lohlker R., Potz R., Muslime in Österreich. Geschichte, Lebenswelt, Religion. Grundlagen für den Dialog, Innsbruck 2012.

Heller H., Muslime in deutscher Erde: Frühe Grabstätten des 14. bis 18. Jahrhunderts [in:] In fremder Erde. Zur Geschichte und Gegenwart der islamischen Bestattung in Deutschland, G. Höpp, J. Gerdien (eds.), Berlin 1996, pp. 45-62.

Holland M.S., Muslimische Bestattungsriten und deutsches Friedhofs- und Bestattungsrecht, Potsdam 2015.

Höpp G., Tod und Geschichte oder Wie in Berlin prominente Muslime bestattet wurden [in:] In fremder Erde. Zur Geschichte und Gegenwart der islamischen Bestattung in Deutschland, G. Höpp, J. Gerdien (eds.), Berlin 1996, pp. 19-44.

Höpp G., Jonker G., In fremder Erde. Zur Geschichte und Gegenwart der islamische Bestattung in Deutschland, Berlin 1996.

Janků T., Islámská funerální kultura jako konfliktni téma v české společnosti [in:] Sborník z IV. mezinárodni vědecké konference studentů doktorských studijnich programů v oblasti společenských věd, T. Hubálek (ed.), Praha 2015, pp. 222-230.

Jennerich L., Islamische Grabfelder in Deutschland, "Friedhofskultur - Zeitschrift für das gesamte Friedhofswesen" 2000, vol. 100, no. 6, pp. 20-23. 
Karakaşoğlu Y., Die Bestattung von Muslimen in der Bundesrepublik aus der Sicht türkisch-islamischer Organisationen [in:] In fremder Erde. Zur Geschichte und Gegenwart der islamischen Bestattung in Deutschland, G. Höpp, J. Gerdien (eds.), Berlin 1996, pp. 83-105.

Klapetek M., Mešita v 'zadním dvoře', "Nový Orient” 2015, vol. 70, no. 1, pp. 2-9.

Klapetek M., Muslimské organizace v Německu, Rakousku a Švýcarsku, Brno 2011.

Klapetek M., Umírání a smrt: Realizace náboženských pravidel v nemuslimském prostředí [in:] Smrt, hroby a záhrobi v islámu. Posledni věci člověka pohledem muslimských prameni̊, B. Ostřanský (ed.), Praha 2014, pp. 249-284.

Kokkelink G., Islamische Bestattung auf kommunalen Friedhöfen [in:] In fremder Erde. Zur Geschichte und Gegenwart der islamischen Bestattung in Deutschland, G. Höpp, J. Gerdien (eds.), Berlin 1996, pp. 63-82.

Kolb J., Mattausch-Y1ldız B., Muslimische Alltagspraxis in Österreich, Vienna 2014.

Lemmen T., Islamische Bestatung in Deutschland. Eine Handreichung, Altenberge 1999.

Lemmen T., Islamische Organisationen in Deutschland, Bonn 2000.

Lemmen T., Muslimische Grabfelder in Deutschland [in:] Sunna leben. Zur Dynamik islamischer Religionspraxis in Deutschland, P. Schrode, U. Simon (eds.), Würzburg 2012, pp. 87-102.

Lohmann S., Mit Blick gen Mekka, "Friedhofskultur - Zeitschrift für das gesamte Friedhofswesen" 2011, vol. 101, no. 7, pp. 28-29.

Malecká J., Narození, svatba a pohřeb v sunnitském islámu, Brno 2014.

Morgenroth A., Lauritzen F., Chancen für das deutsche Friedhofswesen, "Friedhofskultur Zeitschrift für das gesamte Friedhofswesen" 2011, vol. 101, no. 7, pp. 25-27.

Muslims in the Enlarged Europe: Religion and Society, B. Maréchal, S. Allievi, F. Dassetto, J. Nielsen (eds.), Leiden 2003.

Orossová E., Bezproblémová výstavba? Mešity Merkez a Zentralmoschee, diskuze klíčových aktérů a integrace muslimů v současném Německu, "Pantheon" 2015, vol. 10, no. 2, pp. 21-36.

Orszulak-Dudkowska K., Przestrzeń cmentarza w historii kultury europejskiej [in:] Ars moriendi, ars vivendi, ars educandi, Z. Rudnicki (ed.), Poznań 2012, pp. 369-388.

Rohe M., Der Islam - Alltagskonflikte und Lösungen, Freiburg im Breisgau 2001.

Rohe M., Der Islam in Deutschland: Eine Bestandsaufnahme, Munich 2016.

Roose E., Mosque Design and Muslim Patrons in the Netherlands. The Quest for the Ultimate Islamic Construction [in:] The Mosque: Political, Architectural and Social Transformations, E. Erkoçu, C. Buğdacı (eds.), Rotterdam 2009, pp. 114-126.

Roose E., The Myth of the Orientalist Mosque. Towards an Iconography of Islamic Architecture in the Netherlands, "Canadian Journal of Netherlandic Studies" 2012/2013, no. 2/1, pp. 83-106.

Sakaranaho T., Religious Freedom, Multiculturalism, Islam, Leiden 2006.

Sörries R., Der Trend zum multikulturellen Friedhof in Deutschland [in:] Muslime in deutscher Erde. Sterben, Jenseitserwartung und Bestattung, R. Sörries (ed.), Kassel 2009, pp. 13-15.

Sörries R., Muslime in deutscher Erde. Sterben, Jenseitserwartung und Bestattung, Kassel 2009.

Sörries R., Von Mekka bis Berlin. Archäologie und Kulturgeschichte des islamisches Friedhofs, Wiesbaden 2015.

Stichs A., Wie viele Muslime leben in Deutschland?, Nuremberg 2016.

Tan D., Wandlungen des Sterbens und der Trauerrituale in der Migration [in:] In fremder Erde. Zur Geschichte und Gegenwart der islamischen Bestattung in Deutschland, G. Höpp, J. Gerdien (eds.), Berlin 1996, pp. 107-130.

Venhorst C., Muslims Ritualising Death in the Netherlands, Berlin 2013.

Vladi F., Sterben, Jenseitserwartung und Bestattung - Muslime in deutscher Erde [in:] Muslime in deutscher Erde. Sterben, Jenseitserwartung und Bestattung, R. Sörries (ed.), Kassel 2009, pp. 29-36.

Yildiz H., Muslimische Sterbekassen in Deutschland [in:] Muslime in deutscher Erde. Sterben, Jenseitserwartung und Bestattung, R. Sörries (ed.), Kassel 2009, pp. 65-68. 